\title{
Sustenance and sustainability: Food remains and contact sites in Vanuatu
}

\author{
James Flexner, Edson Willie and Mark Horrocks
}

\section{Introduction}

Food is intimately linked to notions of cultural identity and belonging (Twiss 2007, 2015). For Melanesian Islanders, aelan kaekae (island food; Figure 9.1) is a ubiquitous part of everyday experience. Tubers, especially yams and taro, tree crops such as breadfruit and coconut, bananas, tropical fruits, fish and shellfish are heavily showcased on Islander plates, along with ritually important pigs on special occasions. Foods are traditionally cooked over open wood fires, or in earth ovens, which are necessary for making the well-loved delicacy of lap lap (a kind of starchy pudding). Increasingly in the modern era, these foods are supplemented with imported rice, noodles, and tinned meats and fish (e.g. Errington et al. 2013:83-101; Gewertz and Errington 2010). There is a longer history of colonial exchanges of foods in Melanesia, which we examine here using recent examples from mission sites and surrounding areas in southern Vanuatu. The 'mixing' of Melanesian and introduced ingredients in Islander meals can be seen as reflective of an ongoing process of successful negotiations of colonialism and modernity while also maintaining an overarching sense of kastom, or tradition (e.g. Flexner 2016a).

The idea that particular dishes or ingredients represent the 'pure' form of authentic cuisine is philosophically untenable in regards to the colonial period (see Flexner 2017). It also is likely not realistic for any period of human history, as any notion of culinary purity ignores the reality that people have been exchanging, transforming and remixing ingredients and recipes for millennia. On the other hand, it is also inappropriate to ignore the political reality that culinary exchanges did not (and do not) always occur on equal terms. Further, there are certain traditional culinary practices that are integral to local cultural and ecological sustainability in many cases, and we should not ignore neocolonial processes that might damage these practices. Food exists at a complex nexus between global and local forces, which has real ramifications for cultural practices, identities and ecologies as they change through time (Paolisso 2007; Tarble 2008; Wilk 1999). 


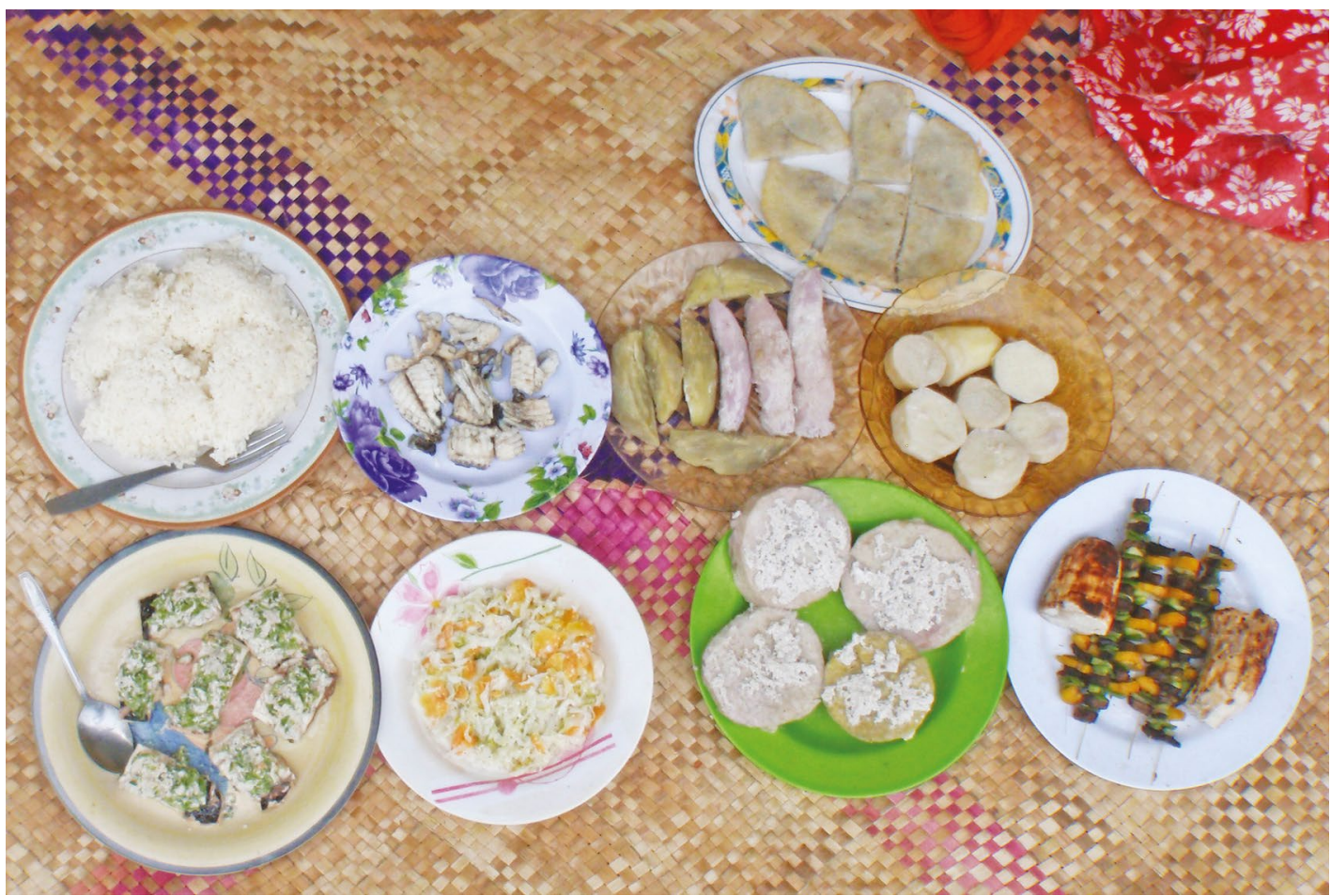

Figure 9.1. A typical Melanesian spread. Note the addition of white rice and instant noodles to the traditional yams, fish, bananas and fruit.

Source: James Flexner.

Appropriation, at least in regards to food, has been a part of human society for millennia. Food appropriation describes the exchange of ingredients, recipes, technologies of preparation or general ideas about cuisine. Food appropriation does not necessarily reflect inherently unequal social or political relationships. In contrast, culinary imperialism represents a more specific case of food appropriation based on the existence of unequal power relations in economic, political, racial or other terms (Flexner 2015). Culinary imperialism can occur where a dominant group's cuisine spreads into the cultures of colonised or subaltern peoples. It can also involve the dominant group taking the ingredients or recipes of a subaltern group, and repurposing or recasting the appropriated cuisine in elite terms and for elite purposes.

To explore this distinction, we turn to a series of case studies from the historical archaeology of mission sites in southern Vanuatu. Using data from a sample of excavated mission sites and Melanesian villages, we explore the role that food played during a series of initial cross-cultural encounters with Presbyterian missionaries on the islands of Tanna and Erromango in the mid-1800s. As we will see, the relationship between food appropriation and culinary imperialism is not a simple either-or distinction. Rather, it is a nested relationship: cross-cultural interactions often resulted in food appropriation, and some of those interactions were structured by colonial inequalities. Further, the exchange of foods in mission interactions, and other interactions with foreigners, were part of a broader pattern of integration of foreign objects and concepts (including the foreign god of Christian missionaries, see Flexner 2016a), which were then subsumed into Melanesian kastom. 


\section{Early southern Vanuatu mission encounters}

The history of mission encounters in southern Vanuatu is a complex one, involving dramatic martyrdoms, heroic efforts by Samoan teachers (themselves only recent converts to Christianity), significant cultural misunderstandings, the creation of friendships, entanglement in local political struggles in the region, catastrophic setbacks and eventually the establishment of large, elaborate mission complexes that won large numbers of converts (Adams 1984; Flexner 2016a; Miller 1978, 1981). Here we focus on early Presbyterian mission sites inhabited from 1856 to 1862. During this time missionaries were able to establish footholds on Tanna and Erromango, but were unable to have a dominant influence among Tannese and Erromangan people. The mission sites that date to this time period saw minimal investment in infrastructure, and were temporary in nature. On both Tanna and Erromango, missionaries were either killed or driven off in 1861-62, often in response to major epidemics for which the evangelists were held responsible (Adams 1984:143-145; Gordon 1863:184-203; Patterson 1864:494-498).

One of the common threads of these encounters is material exchange, which mediated the relationships between Melanesians and Presbyterian missionaries. European-derived material culture both provided a sense of identity for the missionaries themselves, and was intended to serve as 'curiosities' to draw Melanesians into the sphere of missionary influence (Flexner and Ball 2016). In contrast, introduced items in surrounding Melanesian villages were remarkably uncommon, despite what mission-era documents suggest about the importance of material exchange to the work of conversion (Flexner et al. 2016). Another line of evidence that presents a clearer picture of the Melanesian contribution to mission exchanges is the ethnographic collections of Islander 'curiosities' that were integrated into mission houses in the field (e.g. Smith 2005:273), and eventually filtered into museum collections around the world (Flexner 2016b).

Returning to food, it is clear that ingredients, recipes and traditions were also exchanged during interactions between missionaries and Melanesian Islanders. Missionaries were, to some extent, dependent upon local garden surpluses for survival. HA Robertson, missionary on Erromango from 1872, describes the local cuisine at length and with great appreciation. The local diet consisted of tubers, particularly taro and yams, bananas, breadfruit, various fruits, fish and shellfish. Further, certain recipes were described as particularly delicious, such as neoki, a starchy pudding of yam or papaya, prawns and coconut (Robertson 1902:376-381). On the other side, bread was an essential element of missionary cuisine. Making bread was part of the everyday routine around the mission house, a connection to old European baking traditions (e.g. Patterson 1864:452; Watt 1896:81). But for Christian missionaries, bread was more than just a form of sustenance. The symbolic element of bread cannot be ignored for its iconographic centrality to Christianity (e.g. Patterson 1864:151, 158), allowing missionaries to remember the Last Supper with each meal as they prayed over their food. Again, these meals likely featured both European and Melanesian dishes (e.g. Watt 1896:84).

\section{The sites}

Faunal and plant microfossil data from four sites, two from Erromango and two from Tanna (Figure 9.2), reflect the archaeological residues of these kinds of culinary exchanges in the New Hebrides. The sampled sites include one early mission site from each island, and one nearby site of indigenous Melanesian occupation. These sites were test excavated, and 100 per cent of the recovered faunal assemblage was analysed. Bulk sediment samples were collected during excavation, and plant microfossils were identified from a selection of these. 


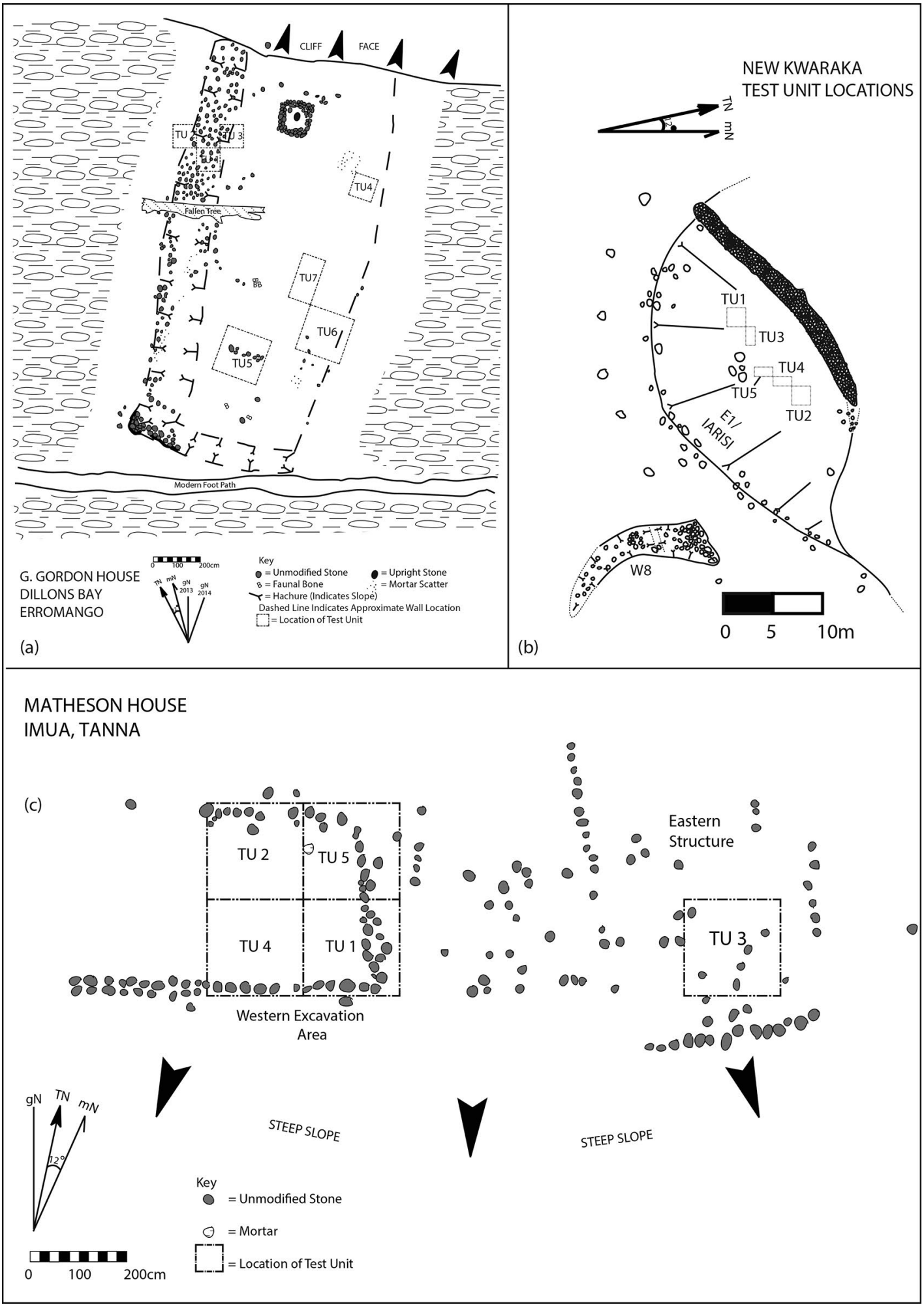

Figure 9.2. Plan maps of excavated areas: (a) G. Gordon House, Dillon's Bay, Erromango; (b) 'New Kwaraka', Kwamera area, Tanna; (c) Imua Mission House, Kwamera area, Tanna. Source: James Flexner. 


\section{Undam}

The site of Undam is located in an area that continues to be actively gardened near the Williams River, Dillon's Bay, Erromango. After local discovery of indigenous pottery, a single test pit was excavated in the area, which yielded shells, charcoal and fire-cracked rock. One of the sediment samples from this test pit, taken from 10-20 cm below the surface, was analysed. This deposit is undated, though the test pit did not contain any introduced material. While it is likely the stratigraphy has been disturbed by recent planting activity, we believe the faunal and plant microfossil signatures (discussed below) would be representative of a longer history of Melanesian landscape management and subsistence patterns. Undam is on the opposite bank and upriver from the later mission site occupied by the Gordons at Dillon's Bay.

\section{G. Gordon House}

G. Gordon House was inhabited by Canadian missionaries George and Ellen Gordon from 1856 to 1861 (Gordon 1863; Robertson 1902). The house is located high on a cliff overlooking the Williams River in Dillon's Bay, and was somewhat remote from the primary villages in the area at the time it was occupied. We excavated a series of test units across this site (Figure 9.2a), which gave us a sample of material culture and allowed us to generally understand that this was a relatively small, simple lime mortar house built with minimal imported materials. We recovered a modest assemblage of European artefacts, including iron nails, bottle glass, transfer-printed whiteware and a single sherd of Chinese porcelain from this site. Our plant microfossil samples come from the occupation and abandonment layers of the house in TU5 and TU6. The site was abandoned in 1861 after the Gordons were killed by local warriors, and the presence of a high percentage of burned glass artefacts in the assemblage suggests that their house was burned shortly thereafter (see Flexner 2016a:26-36 for a more detailed account).

\section{New Kwaraka}

The Melanesian village site from Tanna is associated with a significant local oral tradition (Flexner et al. 2016). Yeni Iarisi, the chief of the village of Kwaraka in the 1850s, travelled to neighbouring Aneityum, where he saw the work of John Geddie, resident missionary on the island from 1848, and recently converted Aneityumese teachers. Liking what he saw, Iarisi decided to bring the Gospel to Tanna, returning to arrange for the settlement of teachers and conversion of his village. This caused tensions in the community, and Iarisi moved with a small group of followers to a site across the river from the main village at a place called Anuikaraka (current social memories term the site 'New Kwaraka').

Following from the oral tradition, we excavated five $2 \times 2 \mathrm{~m}$ and $1 \times 2 \mathrm{~m}$ test units inside the stone enclosure remembered as the site of New Kwaraka. The site yielded very little in the way of imported material culture (a single pipe bowl fragment is the one likely 19th-century artefact), though we did recover large quantities of charcoal and shell. The plant microfossil samples come from the most likely occupation layers of TU1, TU2 and TU3 (Figure 9.2b).

In addition, we excavated a $1 \times 6 \mathrm{~m}$ trench across a conical mound down the hill. These excavations yielded no European material, and radiocarbon dates indicate that the mound was constructed sometime between the late-1600s and mid-1700s, which predates European contact in the region. The mound contained large shells, pig bone and red ochre, and these artefacts suggest some kind of ritual activity in the area. Plant microfossil samples were taken from the stone construction fill of the mound, and the underlying layer, which we interpret as the original ground surface from before the mound was constructed. 


\section{Imua}

The mission site at Imua (a local orthography of 'Samoa' in honour of the original missionary teachers in the area) was inhabited by Canadian missionaries John and Mary Matheson from 1861 to 1862 . The Mathesons had initially settled near Kwamera, south Tanna, in 1858, but they left Tanna in 1860 due to illness, travelling to Aneityum (Mary Matheson was John Geddie's niece) and Erromango, where they almost certainly stayed at the Gordons' house (Adams 1984; Patterson 1864). Upon returning to Tanna, the Mathesons built a wattle and mortar house on a hill overlooking the main harbour where the air was thought to be 'healthier'. Unfortunately, their fortunes were not much better than the Gordons' and they had to flee in February 1862. Excavation of the site revealed a dense abandonment deposit containing a remarkable assemblage of artefacts, including a matched set of transfer-printed ceramics with pastoral motifs (Flexner and Ball 2016). Essentially, as they fled, the Mathesons appear to have left most of the domestic material culture in place. Plant microfossil samples from Imua came from the abandonment layer in each of the five excavated $2 \times 2 \mathrm{~m}$ units (Figure 9.2c).

\section{Faunal analysis results}

Local shellfish were a prominent feature of colonial diets in the New Hebrides. Faunal data from the four excavated sites reflects regular use of shellfish as an ingredient in the diets of both missionaries and Melanesians (Table 9.1). Missionaries appear to have been almost entirely reliant on local seafood as their primary source of protein. Presumably this could have been supplemented occasionally by salted beef or pork, which would not necessarily leave an archaeological trace. We believe salted meat would have been a rare element of missionary diet, as the mission supply ships did not visit often during the 1860s.

Table 9.1. Faunal remains (number of identified specimens and weight) from Vanuatu mission sites.

\begin{tabular}{|c|c|c|c|c|c|c|c|c|c|c|}
\hline & G. Gol & rdon House & Imu & a Mission & New & Kwaraka & & Indam & To & als \\
\hline Taxon & Count & Weight $(g)$ & Count & Weight (g) & Count & Weight (g) & Count & Weight (g) & Total (Count) & Total (Weight) \\
\hline Arcidae & & & \begin{tabular}{|l|}
19 \\
\end{tabular} & \begin{tabular}{|r|}
14.33 \\
\end{tabular} & & & & & 19 & 14.33 \\
\hline Arciidae & 1 & 1.3 & & & & & & & 1 & 1.3 \\
\hline Cerithiidae & 2 & 1.31 & 140 & 15.21 & & & & & 142 & 16.52 \\
\hline Conidae & 2 & 2.49 & 18 & 11.36 & & & 1 & 11.31 & 21 & 25.16 \\
\hline Conus & & & 28 & 23.62 & & & & & 28 & 23.62 \\
\hline Cowrie & & & 3 & 2.49 & & & & & 3 & 2.49 \\
\hline Crustacean & & & 1 & 0.005 & & & & & 1 & 0.005 \\
\hline Cymattidae & & & 10 & 4.11 & & & & & 10 & 4.11 \\
\hline Сургаеа & & & 24 & 17.88 & 3 & 8.93 & & & 27 & 26.81 \\
\hline Gafrarium & & & 49 & 26.09 & & & & & 49 & 26.09 \\
\hline Limpet & & & 33 & 3.555 & & & & & 33 & 3.555 \\
\hline Muricidae & 1 & 0.13 & 2 & 1 & & & & & 3 & 1.13 \\
\hline Nerita & & & 28 & 8.405 & & & & & 28 & 8.405 \\
\hline Nerita sp. & 1 & 0.4 & & & & & & & 1 & 0.4 \\
\hline Olividae & & & 1 & 0.2 & & & & & 1 & 0.2 \\
\hline Ostreidae & & & 9 & 6.81 & & & & & 9 & 6.81 \\
\hline Polymesoda & & & 13 & 3.4 & & & & & 13 & 3.4 \\
\hline Pulmonadae & & & 10 & 3.39 & & & & & 10 & 3.39 \\
\hline Strombidae & & & 4 & 0.83 & & & & & 4 & 0.83 \\
\hline Sus scrofa & & & & & 12 & 15.385 & & & 12 & 15.385 \\
\hline Sus(?) & & & & & 34 & 30.98 & & & 34 & 30.98 \\
\hline Tегеbга & & & & & & & 3 & 0.04 & 3 & 0.04 \\
\hline Tridachna sp. & 1 & 0.71 & & & & & & & 1 & 0.71 \\
\hline
\end{tabular}




\begin{tabular}{|c|c|c|c|c|c|c|c|c|c|c|}
\hline \multirow[b]{2}{*}{ Taxon } & \multicolumn{2}{|c|}{ G. Gordon House } & \multicolumn{2}{|c|}{ Imua Mission } & \multicolumn{2}{|c|}{ New Kwaraka } & \multicolumn{2}{|c|}{ Undam } & \multicolumn{2}{|c|}{ Totals } \\
\hline & Count & Weight $(g)$ & Count & Weight $(g)$ & Count & Weight $(g)$ & Count & Weight $(g)$ & Total (Count) & Total (Weight) \\
\hline Triton & & & 59 & 35.69 & & & & & 59 & 35.69 \\
\hline Trochidae & 2 & 2.13 & 36 & 29.89 & & & & & 38 & 32.02 \\
\hline Turbo & 1 & 10.96 & 20 & 23.08 & 97 & 110.455 & & & 118 & 144.495 \\
\hline Turbo sp. & 2 & 0.68 & & & & & & & 2 & 0.68 \\
\hline Unidentified & 12 & 1.65 & 68 & 26.5 & 3 & 2.28 & 10 & 3.97 & 93 & 34.4 \\
\hline Sum of column & 25 & 21.76 & 575 & 257.845 & 149 & 168.03 & 14 & 15.32 & 763 & 462.955 \\
\hline
\end{tabular}

Source: Authors' data.

The shell assemblages of the mission sites appear to be slightly richer, though there might be some issues with preservation and sample size, particularly for the site of Undam, which is represented by a single test pit. Major taxa represented include:

- Undam: Terebra, Conidae;

- Imua: Turbo, Trochidae, Triton, Nerita, Gafrarium, Cypraea, Conidae, Cerithiidae, Arcidae;

- New Kwaraka: Turbo, Cypraea;

- G. Gordon House: Turbo, Trochidae, Tridacna, Nerita, Muricidae, Conidae, Cerithiidae, Arcidae.

It is notable that the richness of European artefacts at Imua was much higher than at G. Gordon House, but the two shell assemblages are comparable. The lower diversity of the shell assemblages at New Kwaraka may be a reflection of poor preservation conditions at the site.

Marine resources including fish, shellfish and crustaceans were probably obtained as gifts or via material exchanges, since missionaries would probably not have had the right to collect resources from the reefs and beaches of Tanna or Erromango. There was some unidentified crustacean shell from Imua, further evidence for reliance on marine sources.

The other significant finding from faunal analysis is the presence of pig in large concentration at TU6 in New Kwaraka. The mound from which these bones come also contained large shells and red ochre, and has been interpreted as a ritual feature. On both Tanna and Erromango, pigs were important in ceremonial exchanges (Spriggs 1986; Spriggs and Wickler 1989). In the early days, it would have been nearly impossible for the missionaries to be able to obtain such a prestige food except on rare occasions, though we note that there is some unidentified mammal bone from Imua, which could be pig, or possibly sheep or goat. Pig is present on later mission sites, such as HA Robertson's house in Dillon's Bay, Erromango (Flexner 2016a:55-57), which may be a reflection of shifting power dynamics as increasing numbers of Melanesian people converted to Christianity.

\section{Plant microfossils}

Sediment samples were analysed for the recovery of pollen, phytoliths and starch grains (Horrocks 2005). Results from plant microfossil analysis likewise indicate that the missionaries relied heavily on local communities for food. Microscopic charcoal, pollen and phytolith evidence from the four excavated sites (Figures 9.3 and 9.4) reflects the landscapes shaped by ground clearing for traditional Melanesian shifting agriculture, which surrounded the mission sites. The typical suite of Oceanic tree crops, especially banana (Musa sp.) coconut (Cocos nucifera) and screwpine (Pandanus sp.) are particularly prominent in the pollen and phytolith assemblages. However, it is interesting to note that screwpine pollen was relatively rare from the Erromango sites. One of the Imua samples yielded a starch grain of cf. lesser yam (Dioscorea esculenta) (starch type 2, Figure 9.4). $N u k$, as the tuber is known in the local Nafe language, would have been a common ingredient on missionary and Melanesian tables alike. 


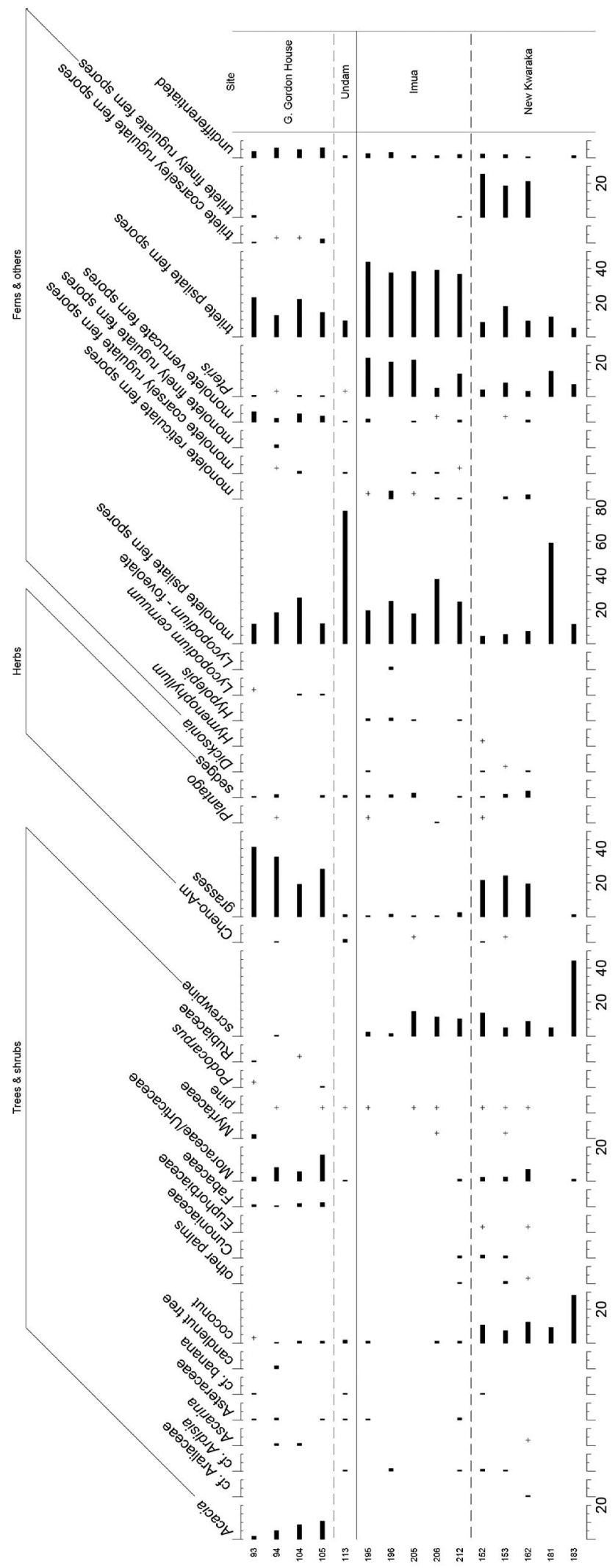

Figure 9.3. Pollen percentage diagram from G. Gordon House and Undam, Erromango Island, and Imua and New Kwaraka, Tanna Island (+ = found after count).

Source: Mark Horrocks. 


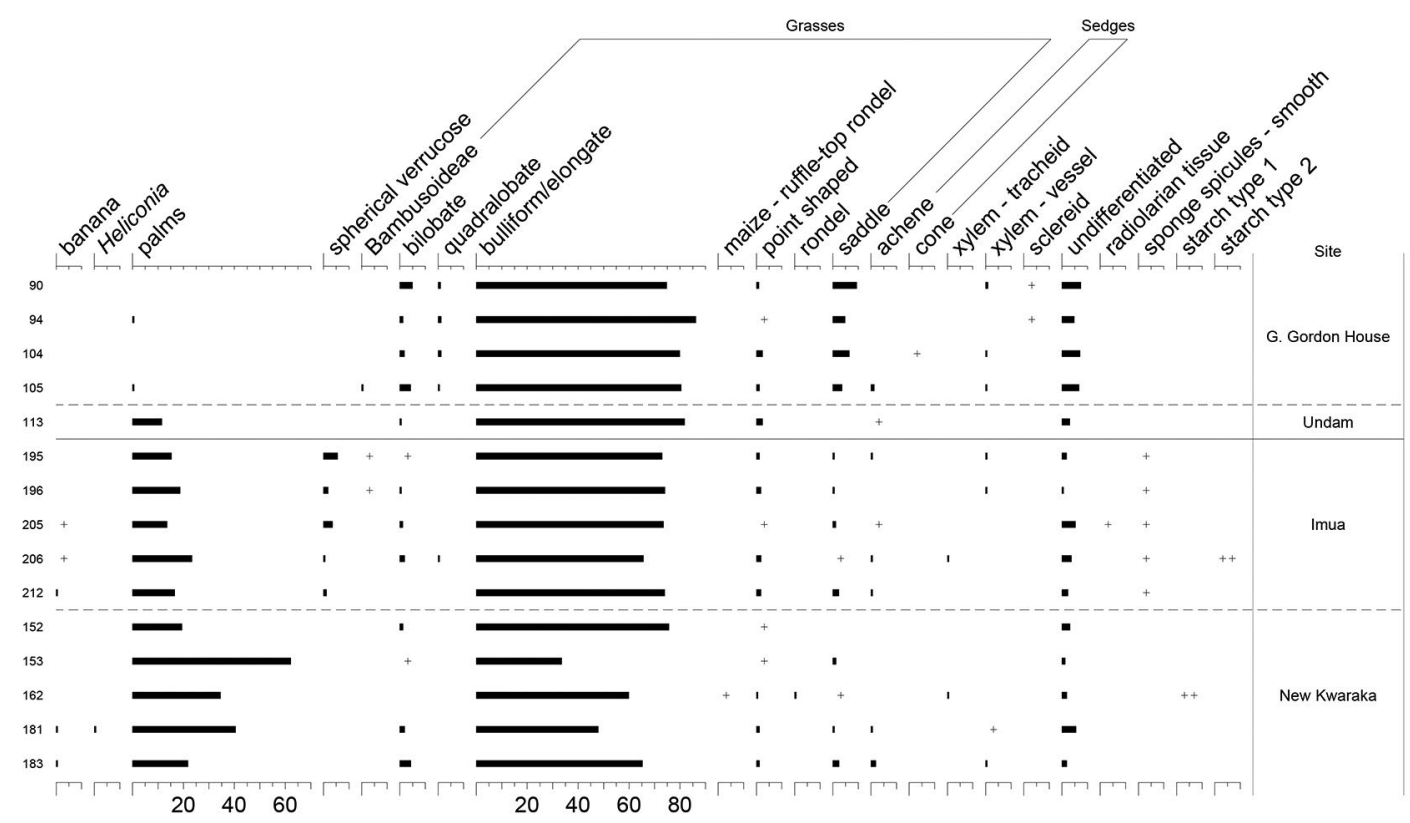

Figure 9.4. Phytolith percentage and starch diagram from G. Gordon House and Undam, Erromango Island, and Imua and New Kwaraka, Tanna Island (+ = found after count, ++ = present).

Source: Mark Horrocks.

At New Kwaraka, there was starch identified most likely from sweet potato (Ipomoea batatas) or giant taro (Alocasia macrorrhizos), starch grains of which can be difficult to differentiate (starch type 1, Figure 9.4). Either of these two species would have been common in the local suite of domesticates. Among the New Kwaraka phytoliths was a Heliconia leaf phytolith from the pre-contact TU6 samples. Heliconia indica leaf is still used as a food wrapping today, and has been found in human dental calculus from ancient burials elsewhere in Vanuatu (Horrocks et al. 2014). There is a long history of using leaves to wrap foods that are going to be cooked in the Oceanic earth oven, which continues today. However, it is worth noting that Heliconia remains rare in Pacific archaeological contexts, and considering the diversity of the genus in the Americas, further study is needed to understand the history of this plant in pre-Columbian as well as colonial exchanges in the region. Intriguingly, New Kwaraka also yielded phytoliths of cf. maize (Zea mays) from the contact-era deposits. Thus there also appears to be some degree of a Tannese 'early adoption' of new cultivars brought to the New Hebrides by outsiders, possibly missionaries or early traders. In this case, maize, which is originally a Central American cultigen (Piperno and Flannery 2001), was added to the already rich suite of starchy plant crops grown by Melanesian gardeners.

\section{Historical archaeology perspectives on appropriation, imperialism and sustainability}

Archaeological evidence from contact-era sites on Tanna and Erromango, both mission houses and Melanesian villages, reflects patterns of continuity and change in the plant and animal foods that characterised the diets of foreign missionaries and indigenous people. Food was often the first thing exchanged with European visitors in the Pacific, and this was the case in Vanuatu (e.g. Beaglehole 1969:501-502). Island cuisine, based on an abundance of root crops, starchy puddings, greens, coconut cream and seafood, is an integral part of Pacific peoples' identities 
and ways of life. It is clear that in the case of the mission sites, missionaries not only integrated island foods into their own tables, but they were in fact reliant on Melanesian foods, particularly on seafood as a protein source. While the plant microfossils are not necessarily direct evidence of food consumption on mission sites, as they might have been carried by wind or washed into the sediment by rain, they do represent the kinds of plant crops that were present in the landscape during the mid-1800s. On the other hand, the documentary evidence (described above) does represent the extent to which local cuisine was present on missionary tables.

At the same time, Pacific Islanders were also great adapters of introduced crops. The rapid spread of sweet potato throughout much of the Pacific before European contact (e.g. Barber 2012), and into the New Guinea highlands after contact (e.g. Bourke 2009), provides one salient example. The presence of maize in the contact-era deposits at New Kwaraka provides another, and considering the link to oral traditions, it is possible that along with the Gospel, Iarisi brought new crops to south Tanna. Yet not all introduced crops are widely adopted, and maize remains a relatively minor cultigen in contemporary gardens in Vanuatu.

After the 1870s, there was a shift in the power balance of the Vanuatu missions. Missionaries were able to dominate the religious beliefs of rapidly declining Melanesian populations, and at the same time to draw on increasingly efficient global trade networks. Yet evidence from these later missions shows that Melanesian foods continued to be the main portion of the diet, a pattern that continues today in Vanuatu, though this is changing rapidly. Instant noodles, tinned meat and fish, and rice increasingly feature on island tables, a reflection of the ability of mass-produced global food commodities to colonise local diets. This is a worrisome development for Islander health, environments and cultures, though indigenous ni-Vanuatu are making efforts to sustain traditional cuisine. A 'slow food' and 'local food' movement has grown in the last few years, particularly as the Vanuatu Cultural Centre works to promote local foods in island communities. The first Slow Food Festival, held on Tanna in August, 2016 (Guiomar 2016), is a reflection of this positive trend.

In early colonial exchanges, Melanesian people generally had the opportunity to choose which ingredients to adopt from foreigners. Missionaries were dependent on local people, who provided the only source of fresh food, since missionaries would not have had rights to garden plots sufficient to sustain themselves, nor would they have been permitted to gather marine resources. Returning to the concepts introduced above, these exchanges appear to be primarily about food appropriation. It is only really in the post-World War II era that some forms of culinary imperialism are evident in Vanuatu, primarily in relation to the ubiquity of rice, biscuits, instant noodles and tinned fish and meat, and again it is interesting to see resistance to these interloper ingredients.

Food of course is about much more than calories and nutrients. It is also wrapped up in senses of identity and personhood. Food can be symbolically or ritually loaded, as with pigs who are typically only sacrificed on special occasions, or the large ceremonial yams grown on Tanna and Erromango (one such yam observed by missionary George Turner in 1842 was over $1.5 \mathrm{~m}$ long and weighed over $22 \mathrm{~kg}$; Turner 1861:87). If Melanesian personhood and material culture are 'partible' in nature (Gosden 2004:35-39; Strathern 1990), then food is the ultimate partible medium for exchange, as it lends itself so well to being divided and shared. As Lindstrom (2013:263) notes in relation to the experiences of missionary Agnes Watt: 'The Tannese when describing mutual personhood talk in terms of shared blood, shared name, shared place and shared spirit.' To this list we might add shared food as an essential element of Islander practice and belief. 


\section{Acknowledgements}

We would like to thank the people of Tanna and Erromango who were our hosts and in many cases partners in this research. The overall project was funded by an Australian Research Council DECRA (Discovery Early Career Researcher Award) Fellowship (DE130101703) hosted at The Australian National University.

\section{References}

Adams, R. 1984. In the land of strangers: A century of European contact with Tanna, 1774-1874. Canberra: The Australian National University.

Barber, I. 2012. 'A fast yam to Polynesia: New thinking on the problem of the American sweet potato in Oceania'. Rapa Nui Journal 26 (1):31-42.

Beaglehole, JC (ed.). 1969. The journals of Captain James Cook on his voyages of discovery: The voyage of the Resolution and Adventure 1772-1775. Cambridge: The Hakluyt Society.

Bourke, RM. 2009. 'History of agriculture in Papua New Guinea'. In Food and agriculture in Papua New Guinea, edited by RM Bourke and T Harwood, 10-26. Canberra: ANU E Press. doi.org/10.22459/ FAPNG.08.2009.

Errington, F, D Gewertz and T Fujikara. 2013. The noodle narratives: The global rise of an industrial food into the twenty-first century. Berkeley: University of California Press.

Flexner, JL. 2015. 'Food appropriation and culinary imperialism'. In Archaeology of food: An encyclopedia, edited by KC Metheny and MC Beaudry, 201-203. Lanham, MD: Rowman and Littlefield.

Flexner, JL. 2016a. An archaeology of early Christianity in Vanuatu: Kastom and religious change on Tanna and Erromango, 1839-1920. Terra Australis 44. Canberra: ANU Press. doi.org/10.22459/ TA44.12.2016.

Flexner, JL. 2016b. 'Ethnology collections as supplements and records: What museums contribute to historical archaeology of the New Hebrides (Vanuatu)'. World Archaeology 48 (2):196-209. doi.org/ $10.1080 / 00438243.2016 .1195769$.

Flexner, JL. 2017. 'Reform and purification in the historical archaeology of the South Pacific, 1840-1900'. International Journal of Historical Archaeology 21 (4):827-847. doi.org/10.1007/s10761-017-0398-1.

Flexner, JL and AC Ball. 2016. 'Sherds of paradise: Domestic archaeology and ceramic artefacts from a Protestant mission in the South Pacific'. European Journal of Archaeology 19 (4):728-754. doi.org/ 10.1080/14619571.2016.1147319.

Flexner, JL, E Willie, AZ Lorey, H Alderson, R Williams and S Ieru. 2016. 'Iarisi's domain: Historical archaeology of a Melanesian village, Tanna Island, Vanuatu'. Journal of Island and Coastal Archaeology 11 (1):26-49. doi.org/10.1080/15564894.2015.1052865.

Gewertz, D and F Errington. 2010. Cheap meat: Flap food nations in the Pacific Islands. Berkeley: University of California Press.

Gordon, J (ed.). 1863. The last martyrs of Eromanga, being a memoir of the Rev. George N. Gordon, and Ellen Catherine Powell, his wife. Halifax: MacNab and Shafer.

Gosden, C. 2004. Archaeology and colonialism: Cultural contact from 5000 BC to the present. Cambridge: Cambridge University Press. 
Guiomar, O. 2016. 'Tanna hosts Vanuatu’s first "slow foods" festival—big success'. Asia Pacific Report, 31 August. asiapacificreport.nz/2016/08/31/tanna-hosts-vanuatus-first-slow-foods-festival-big-success/.

Horrocks, M. 2005. 'A combined procedure for recovering phytoliths and starch residues from soils, sedimentary deposits and similar materials'. Journal of Archaeological Science 32:1169-1175. doi.org/ 10.1016/j.jas.2005.02.014.

Horrocks, M, MK Nieuwoldt, R Kinaston, H Buckley and S Bedford. 2014. 'Microfossil and Fourier Transform InfraRed analyses of Lapita and post-Lapita human dental calculus from Vanuatu, Southwest Pacific'. Journal of the Royal Society of New Zealand 44:17-33. doi.org/10.1080/03036758 .2013.842177.

Lindstrom, L. 2013. 'Agnes C. P. Watt and Melanesian personhood'. Journal of Pacific History 48 (3):243-266. doi.org/10.1080/00223344.2013.832020.

Miller, JG. 1978. Live: A history of church planting in the New Hebrides, Book I: A history of church planting in the New Hebrides to 1880. Sydney: Committees on Christian Education and Overseas Missions, General Assembly of the Presbyterian Church of Australia.

Miller, JG. 1981. Live: A history of church planting in the New Hebrides, Book II: The growth of the Church to 1880. Sydney: Committees on Christian Education and Overseas Missions, General Assembly of the Presbyterian Church of Australia.

Paolisso, M. 2007. 'Taste the traditions: Crabs, crab cakes, and the Chesapeake Bay blue crab fishery'. American Anthropologist 109 (4):654-665. doi.org/10.1525/aa.2007.109.4.654.

Patterson, G. (ed.). 1864. Memoirs of the Rev. S. F. Johnston, the Rev. J. W. Matheson, and Mrs. Mary Johnston Matheson, missionaries on Tanna, with selections from their diaries and correspondence, and notices of the New Hebrides, their inhabitants, and mission work among them. Philadelphia: W.S. \& A. Martien.

Piperno, DR and KV Flannery. 2001. 'The earliest archaeological maize (Zea mays L.) from highland Mexico: New accelerator mass spectrometry dates and their implications'. Proceedings of the National Academy of Sciences 98 (4):2101-2103. doi.org/10.1073/pnas.98.4.2101.

Robertson, HA. 1902. Erromanga: The martyr isle. Toronto: The Westminster Company.

Smith, AM. 2005. “'Curios” from a strange land: The Oceania collections of the Reverend Joseph Annand'. In Canadian missionaries, indigenous peoples: Representing religion at home and abroad, edited by AJ Austin and JS Scott, 262-278. Toronto: University of Toronto Press.

Spriggs, M. 1986. 'Landscape, land use, and political transformation in southern Melanesia'. In Island societies: Archaeological approaches to evolution and transformation, edited by PV Kirch, 6-19. Cambridge: Cambridge University Press.

Spriggs, M and S Wickler. 1989. 'Archaeological research on Erromango: Recent data on southern Melanesian prehistory'. Bulletin of the Indo-Pacific Prehistory Association 9:68-91. doi.org/10.7152/ bippa.v9i0.11283.

Strathern, M. 1990. The gender of the gift: Problems with women and problems with society in Melanesia. Berkeley: University of California Press.

Tarble, K. 2008. 'Coffee, tea, or chicha? Commensality and culinary practice in the Middle Orinoco following colonial contact'. In Desencuentros culturales: Una mirada desde la cultura material de las América, edited by AR Martinez, 53-71. Barcelona: Universidad Pampeu Fabra.

Turner, G. 1861. Nineteen years in Polynesia: Missionary life, travels, and researches in the islands of the Pacific. London: John Snow. 
Twiss, KC. 2007. 'We are what we eat'. In The archaeology of food and identity, edited by KC Twiss, 1-15. Carbondale: Southern Illinois University Press.

Twiss, KC. 2015. 'Food and identity'. In Archaeology of food: An encyclopedia, edited by KC Metheny and MC Beaudry, 189-190. Lanham, MD: Rowman and Littlefield.

Watt, ACP. 1896. Twenty-five years' mission life on Tanna, New Hebrides. Paisley: J. and R. Parlane.

Wilk, R. 1999. "Real Belizean food": Building local identity in the transnational Caribbean'. American Anthropologist 101 (2):244-255. doi.org/10.1525/aa.1999.101.2.244. 
This text is taken from Archaeologies of Island Melanesia: Current approaches to landscapes, exchange and practice, edited by Mathieu Leclerc and James Flexner, published 2019 by ANU Press, The Australian National University, Canberra, Australia.

doi.org/10.22459/TA51.2019.09 